\title{
Functional Profile Evaluation of Lactobacillus fermentum TCUESC01: A New Potential Probiotic Strain Isolated during Cocoa Fermentation
}

\author{
Tauá Alves Melo, ${ }^{1}$ Thalis Ferreira dos Santos, ${ }^{2}$ Lennon Ramos Pereira, ${ }^{1}$ \\ Hélic Moreira Passos, ${ }^{1}$ Rachel Passos Rezende, ${ }^{1}$ and Carla Cristina Romano ${ }^{1}$ \\ ${ }^{1}$ Department of Biological Sciences, State University of Santa Cruz, Ilhéus-Itabuna Road, Km 16 Salobrinho, 45662-900 Ilhéus, \\ BA, Brazil \\ ${ }^{2}$ Department of Biological Sciences, State University of Feira de Santana, Transnordestina Avenue, S/N, Novo Horizonte, \\ 44036-900 Feira de Santana, BA, Brazil \\ Correspondence should be addressed to Carla Cristina Romano; romanocc@uol.com.br
}

Received 27 March 2017; Revised 16 May 2017; Accepted 20 June 2017; Published 20 July 2017

Academic Editor: Filippo Canducci

Copyright (C) 2017 Tauá Alves Melo et al. This is an open access article distributed under the Creative Commons Attribution License, which permits unrestricted use, distribution, and reproduction in any medium, provided the original work is properly cited.

\begin{abstract}
The use of intestinal probiotic bacteria is very common in the food industry and has been the focus of the majority of research in this field. Yet in recent years, research on extraintestinal microorganisms has greatly increased due to their well-known potential as probiotics. Thus, we studied a strain of Lactobacillus fermentum (TCUESC01) extracted from fermenting cocoa. First, we examined the impact of $\mathrm{pH}$ on the growth of this strain and studied its survival under conditions similar to those of the human gastrointestinal tract. L. fermentum TCUESC01 demonstrated resistance to conditions mimicking the human stomach and intestines and grew well between $\mathrm{pH} 5$ and $\mathrm{pH}$ 7. Next, we subjected $L$. fermentum TCUESC01 to storage at $4^{\circ} \mathrm{C}$ in a milk solution and found that it survived well for 28 days. Lastly, we measured the susceptibility of this strain to numerous antibiotics and its tendency to autoaggregate. $L$. fermentum TCUESC01 showed significant autoaggregation, as well as susceptibility to the majority of antibiotics tested. Overall, our findings support the potential use of this extraintestinal bacterium as a dietary probiotic.
\end{abstract}

\section{Introduction}

The search for new probiotics is motivated by the knowledge that each strain of microorganisms possesses different properties and could have unique effects on human health. Historically, it was believed that the lactic bacteria in probiotic products had to be sourced from humans due to the specificity of the host [1]. However, extraintestinal microorganisms isolated from fermented lactose-containing foods or fermented vegetables also exhibit promising probiotic effects $[2,3]$. Preliminary evidence from our lab indicates that Lactobacillus strains derived from the fermentation of high-quality cocoa exhibit probiotic properties: they reduce histological damage, reduce the systemic concentration of inflammatory cytokines, and increase the serum IgA levels in an in vivo experimental model of colitis [4]. However, the possible use of these strains in commercial products depends on a series of tests recommended by international organizations. According to the Food and Agricultural Organization of the United Nations (FAO) and the World Health Organization (WHO), potential probiotic strains should be evaluated for their functional and technological characteristics, including their resistance during gastrointestinal transit and their stability during storage [5]. Therefore, we evaluated the functional properties and safety of the Lactobacillus fermentum strain TCUESC01 that was isolated during the fermentation of highquality cacao.

\section{Materials and Methods}

2.1. Microorganisms and Growth Conditions. Lactobacillus fermentum TCUESC01 strain (accession number KU244478, 
GenBank (http://www.ncbi.nlm.nih.gov/nuccore/KU244478)) was cultivated in lactobacilli MRS broth ( $1 \%$ peptone, $0.8 \%$ meat extract, $0.4 \%$ yeast extract, $2 \%$ glycose, $0.5 \%$ sodium acetate, $0.2 \%$ dipotassium hydrogen phosphate, $0.02 \%$ magnesium sulfate heptahydrate, $0.005 \%$ manganese sulfate tetrahydrate, and $0.02 \%$ citric acid triammonium salt) (HIMEDIA ${ }^{\circledR}$, India) for $18 \mathrm{~h}$ at $37^{\circ} \mathrm{C}$ and stored at $-80^{\circ} \mathrm{C}$ in a $10 \%$ milk solution (Molico ${ }^{\circledR}$, Brazil) containing 30\% glycerol.

2.2. Analysis of Growth and Viability under Varied $p H$. MRS broth solutions of $\mathrm{pH} 2, \mathrm{pH} 3, \mathrm{pH} 4, \mathrm{pH} 5, \mathrm{pH} 6, \mathrm{pH}$ 7, $\mathrm{pH} 8$, and $\mathrm{pH} 9$ were prepared by addition of $1 \mathrm{~mol} \cdot \mathrm{L}^{-1}$ of hydrochloric acid or $1 \mathrm{~mol} \cdot \mathrm{L}^{-1}$ of sodium hydroxide. Before the trial, L. fermentum TCUESC01 was cultured for $18 \mathrm{~h}$ and then diluted in a saline solution $(0.85 \%$ sodium chloride) to an optical density (OD) of 0.3 as measured at $600 \mathrm{~nm}\left(\mathrm{OD}_{600}=0.3\right)$. The trials were performed in 96well microplates $\left(\operatorname{Costar}^{\circledR}\right)$, wherein $180 \mu \mathrm{L}$ of MRS at each $\mathrm{pH}$ was inoculated with $20 \mu \mathrm{L}$ of active culture or saline as a control. The microplate was incubated at $37^{\circ} \mathrm{C}$ and the OD at $600 \mathrm{~nm}$ was determined hourly for $10 \mathrm{~h}$ using a spectrophotometer (Molecular Devices ${ }^{\circledR}$, Versamax tunable microplate reader). In parallel, samples were taken every hour from each $\mathrm{pH}$, plated on MRS agar, and incubated under anaerobic conditions at $37^{\circ} \mathrm{C}$ to test cell viability.

2.3. In Vitro Tolerance to Gastrointestinal Conditions. Bacteria were cultured at $37^{\circ} \mathrm{C}$ overnight in $40 \mathrm{~mL}$ of MRS broth, washed in a saline solution, and inoculated into $20 \mathrm{~mL}$ of a $10 \%$ milk solution. Milk fermentation was allowed to proceed until a $\mathrm{pH}$ of 4.5 was reached, at which point the bacteria were counted (CFU.mL ${ }^{-1}$ ) by serial dilution and plating on MRS agar. In addition, a serial dilution was done in a saline solution $(\mathrm{pH} 2.5)$ with pepsin $(3 \mathrm{~g} / \mathrm{L})$, followed by incubation at $37^{\circ} \mathrm{C}$ for $1.5 \mathrm{~h}$. Bacteria were washed by two cycles of centrifugation $(5000 \times \mathrm{g} / 10 \mathrm{~min})$ and resuspension in a saline solution, before being resuspended in $20 \mathrm{~mL}$ of $1 \%$ porcine bile at $\mathrm{pH} 8.0$ (Merck ${ }^{\circledR}$, Germany) and incubated at $37^{\circ} \mathrm{C}$ for 45 minutes. The bacterial counts $\left(\mathrm{CFU} \cdot \mathrm{mL}^{-1}\right)$ were determined by plating the bacterial solution in MRS agar under anaerobic conditions at $37^{\circ} \mathrm{C}$ for $48 \mathrm{~h}$ after each incubation phase.

2.4. Survival during Cold Storage in Acidified Milk. The L. fermentum strain TCUESC01 was cultured in MRS broth and then harvested by centrifugation $(5000 \times \mathrm{g} / 10 \mathrm{~min})$. The bacteria were then washed by resuspension in a saline solution and again pelleted by centrifugation. The cultures were inoculated into a sterile solution of $10 \%$ nonfat milk that had been acidified to $\mathrm{pH} 4.5$ with lactic acid (Synth ${ }^{\circledR}$, Brazil). The lactic solution was refrigerated at $4^{\circ} \mathrm{C}$ and the colonyforming units $\left(\mathrm{CFU} \cdot \mathrm{mL}^{-1}\right.$ ) were counted by serial dilution and plating on MRS agar at $0,7,14,21$, and 28 days. The viability of the strain was determined in relation to the zero time point, which was considered to have $100 \%$ survival.

2.5. Analysis of Autoaggregation. L. fermentum TCUESC01 was cultured in $20 \mathrm{~mL}$ of MRS broth overnight at $37^{\circ} \mathrm{C}$. The bacterial pellet was collected and resuspended in saline
TABLE 1: Standards for interpreting the zones of inhibition for specific antibiotics.

\begin{tabular}{|c|c|c|c|c|}
\hline \multirow{2}{*}{ Antibiotic } & \multirow{2}{*}{$\begin{array}{l}\text { Amount on } \\
\text { disc } \mu \mathrm{g}\end{array}$} & \multicolumn{3}{|c|}{ Zone of inhibition (mm) } \\
\hline & & $R$ & MS & $S$ \\
\hline $\begin{array}{l}\text { Amoxicillin and } \\
\text { clavulanic acid }\end{array}$ & 30 & $\leq 18$ & $19-20$ & $\geq 21$ \\
\hline Amikacin & 30 & $\leq 15$ & $16-17$ & $\geq 18$ \\
\hline Amoxicillin & 10 & $\leq 13$ & $14-16$ & $\geq 17$ \\
\hline Azithromycin & 15 & $\leq 2$ & 4 & $\geq 8$ \\
\hline Cefalotin & 30 & $\leq 14$ & $15-17$ & $\geq 18$ \\
\hline Cefotaxime & 30 & $\leq 14$ & $15-22$ & $\geq 23$ \\
\hline Cefoxitin & 30 & $\leq 14$ & $15-17$ & $\geq 18$ \\
\hline Ciprofloxacin & 5 & $\leq 13$ & $14-18$ & $\geq 19$ \\
\hline Clindamycin & 2 & $\leq 8$ & $9-11$ & $\geq 12$ \\
\hline Chloramphenicol & 30 & $\leq 13$ & $14-17$ & $\geq 18$ \\
\hline Cotrimoxazole & 25 & $\leq 10$ & $11-15$ & $\geq 16$ \\
\hline Erythromycin & 15 & $\leq 13$ & $14-17$ & $\geq 18$ \\
\hline Streptomycin & 10 & $\leq 11$ & $12-14$ & $\geq 15$ \\
\hline Gentamicin & 10 & $\leq 12$ & - & $\geq 13$ \\
\hline Imipenem & 10 & $\leq 13$ & $14-15$ & $\geq 16$ \\
\hline Norfloxacin & 10 & $\leq 13$ & $14-18$ & $\geq 19$ \\
\hline Penicillin G & 10 & $\leq 19$ & $20-27$ & $\geq 28$ \\
\hline Sulfonamides & 300 & $\leq 12$ & $13-16$ & $\geq 17$ \\
\hline Tetracycline & 30 & $\leq 14$ & $15-18$ & $\geq 19$ \\
\hline Vancomycin & 30 & $\leq 14$ & $15-16$ & $\geq 17$ \\
\hline
\end{tabular}

${ }^{*}$ Ranges of zone of inhibition diameters exhibited by bacteria considered susceptible $(S)$, moderately susceptible (MS), or resistant $(R)$ to each antibiotic are shown [6-8].

solution to an $\mathrm{OD}$ of 0.3 at $600 \mathrm{~nm}\left(\mathrm{OD}_{600}=0.3\right)$. The capacity of $L$. fermentum TCUESC01 for autoaggregation was tested by incubating the suspension in at $37^{\circ} \mathrm{C}$ and the OD was monitored hourly for $5 \mathrm{~h}$. The percent aggregation $(\% A)$ was calculated as follows:

$$
\% A=\left[\frac{\left(\mathrm{OD}_{i}-\mathrm{OD}_{f}\right)}{\left(\mathrm{OD}_{i}\right)}\right] \times 100 \%,
$$

where $\mathrm{OD}_{i}$ is the initial optical density at the zero time point and $\mathrm{OD}_{f}$ is the optical density at the time of the measurement. The results shown were the averages plus/minus the standard deviations from three experiments.

2.6. Antibiotics Susceptibility Testing. L. fermentum TCUESC01 was grown for $18 \mathrm{~h}$ in MRS broth at $37^{\circ} \mathrm{C}$ and diluted to 0.5 on the McFarland scale in a saline solution. Antibiotic discs were placed on Mueller-Hinton agar plates that were then inoculated with $100 \mu \mathrm{L}$ of the active bacteria suspension. The plates were then incubated under anaerobic conditions for $24 \mathrm{~h}$ at $37^{\circ} \mathrm{C}$. The zones of inhibition around the discs were measured and the bacteria were classified as resistant $(R)$, moderately susceptibility (MS), or susceptible $(S)$ based on the standards outlined in Table 1 . The antibiotic discs used in the susceptibility test were amoxicillin (AMO, LABORCLIN ${ }^{\circledR}$, Brazil, $10 \mu \mathrm{g}$ ), ciprofloxacin (CIP, 


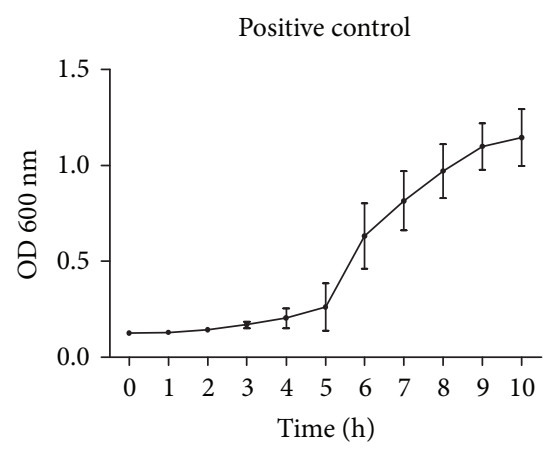

(a)

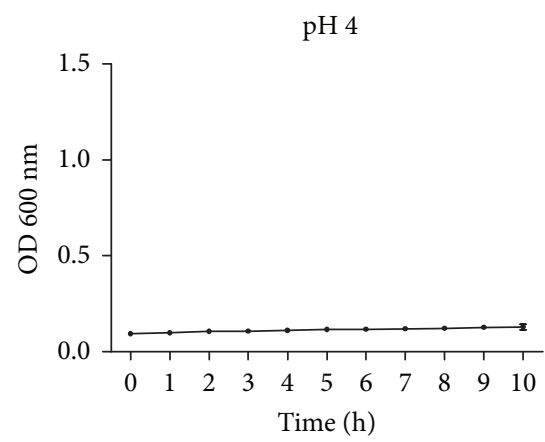

(d)

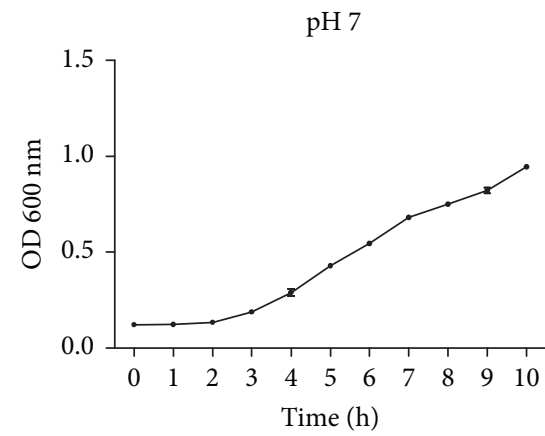

(g)

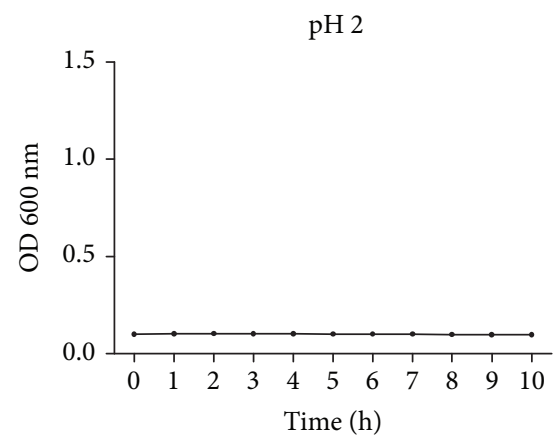

(b)

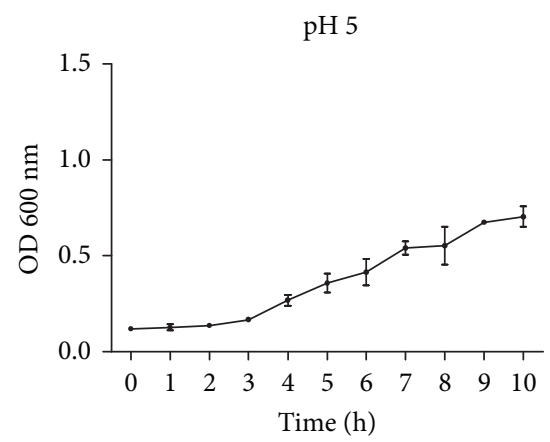

(e)

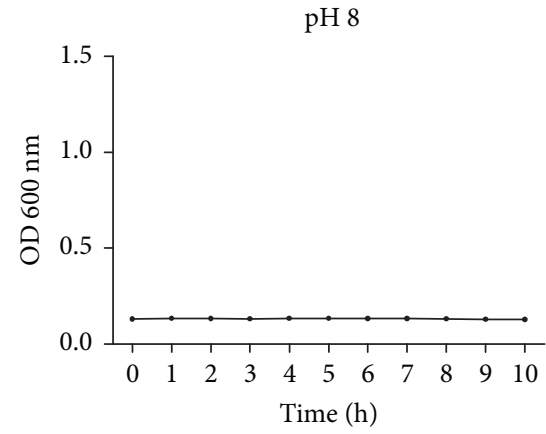

(h)

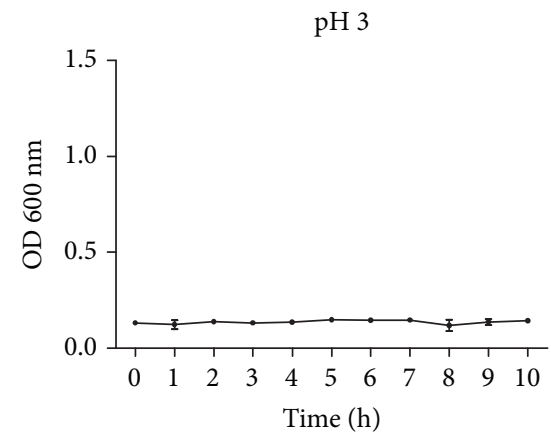

(c)

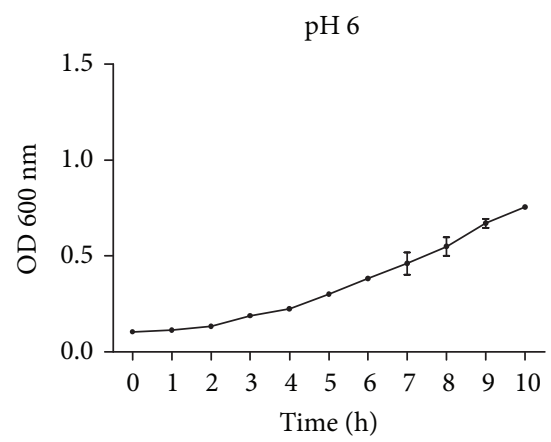

(f)

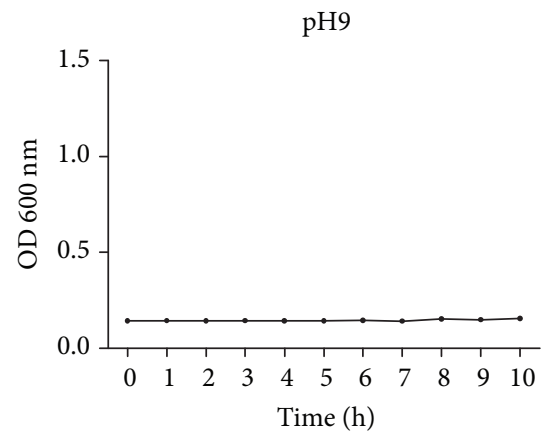

(i)

FIGURE 1: Growth of Lactobacillus fermentum TCUESC01 in the period from 0 to 10 hours of cultures at $37^{\circ} \mathrm{C}$ in different $\mathrm{pH}$ : (a) growth in MRS without modification of $\mathrm{pH}$ (pH 6.52); (b) growth in MRS with pH 2; (c) growth in MRS with pH 3; (d) growth in MRS with pH 4; (e) growth in MRS with pH 5; (f) growth in MRS with pH 6; (g) growth in MRS with pH 7; (h) growth in MRS with pH 8; (i) growth in MRS with $\mathrm{pH}$ 9. Each point of the graphic represents the average and the standard deviation from three experiments.

LABORCLIN, Brazil, $5 \mu \mathrm{g}$ ), amikacin (AMI, CECON ${ }^{\circledR}$, Brazil, $30 \mu \mathrm{g}$ ), azithromycin (AZI, CECON, Brazil, $15 \mu \mathrm{g}$ ), amoxicillin and clavulanic acid (AMC, SENSIFAR ${ }^{\circledR}$, Brazil, $30 \mu \mathrm{g}$ ), norfloxacin (NOR, LABORCLIN, Brazil, $10 \mu \mathrm{g}$ ), sulfonamide (SUL, NEWPROV ${ }^{\circledR}$, Brazil, $300 \mu \mathrm{g}$ ), vancomycin (VAN, SENSIFAR, Brazil, $30 \mu \mathrm{g}$ ), streptomycin (EST, LABORCLIN, Brazil, $10 \mu \mathrm{g}$ ), erythromycin (ERI, CECON, Brazil, $15 \mu \mathrm{g}$ ), tetracycline (TET, SENSIFAR, Brazil, $30 \mu \mathrm{g}$ ), imipenem (IPM, CECON, Brazil, $10 \mu \mathrm{g}$ ), cefalotin (CFL, LABORCLIN, Brazil, $30 \mu \mathrm{g}$ ), gentamicin (GEN, CECON, Brazil, $10 \mu \mathrm{g}$ ), cefotaxime (CTX, SENSIFAR, Brazil, $30 \mu \mathrm{g}$ ), cotrimoxazole (trimethoprim and sulfamethoxazole) (SUT, SENSIFAR, Brazil, $25 \mu \mathrm{g}$ ), chloramphenicol (CLO, SENSIFAR, Brazil, $30 \mu \mathrm{g}$ ), clindamycin (CLI, CECON, Brazil,
$2 \mu \mathrm{g}$ ), penicillin G (PEN10, CECON, Brazil, $10 \mu \mathrm{g}$ ), and cefoxitin (CFO, LABORCLIN, Brazil, $30 \mu \mathrm{g}$ ).

2.7. Statistical Analyses. The calculations of means and standard deviations, the analyses of variance, Tukey's Multiple Comparison Tests, and all statistical analyses were done using the GraphPad ${ }^{\circledR}$ Prism 5.0 software program. All graphs were also produced using the GraphPad Prism 5.0 program.

\section{Results}

3.1. Effect of $p H$ on L. fermentum TCUESC01 Growth and Viability. L. fermentum TCUESC01 was able to grow in media at $\mathrm{pH} 5, \mathrm{pH}$ 6, and $\mathrm{pH} 7$ (Figure 1). However, growth was not observed outside this $\mathrm{pH}$ range (Figure 1). 


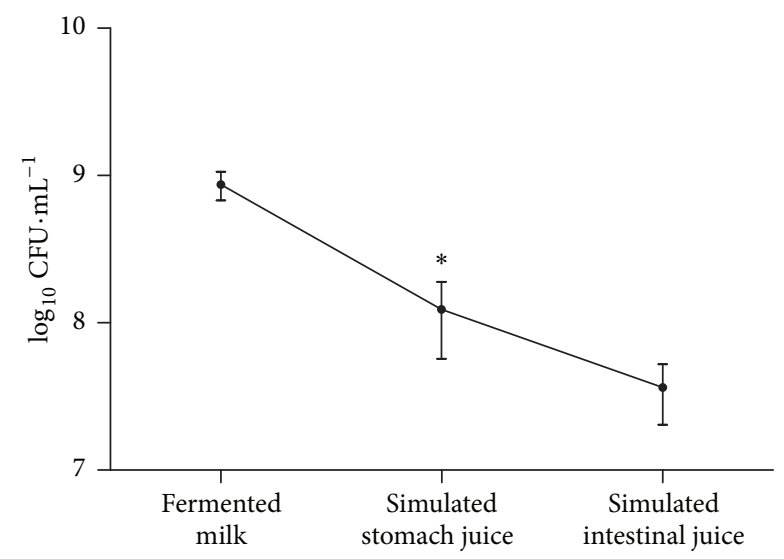

FIGURE 2: Survival of Lactobacillus fermentum TCUESC01 during passage through the simulated gastrointestinal tract. "Fermented milk" after fermentation of the milk; "simulated stomach juice" after passage in saline $\mathrm{pH} 2.5+$ pepsin; "simulated intestinal juice" after passage in ox bile $1 \%$. Each point on the graph represents the average and standard deviant of three experiments. * Statistically significant reduction $(p<0.05)$ in relation to "fermented milk."

3.2. Tolerance of L. fermentum TCUESC01 to Gastrointestinal Conditions In Vitro. The tolerance of L. fermentum TCUESC01 to gastrointestinal passage was evaluated under conditions designed to mimic the human gastrointestinal tract (Figure 2). A bacterial solution was grown to a concentration of $8.7 \times 10^{8} \mathrm{CFU} \cdot \mathrm{mL}^{-1}$ in a $10 \%$ milk solution. After submitting the bacteria to a solution containing pepsin at $\mathrm{pH} 2.5$ for $1.5 \mathrm{~h}$ to simulate gastric juice, we observed a statistically significant reduction $(p<0.05)$ of the bacterial concentration to $1.23 \times 10^{8} \mathrm{CFU} \cdot \mathrm{mL}^{-1}$. After being washed with saline, the bacteria were then subjected to a solution of $1 \%$ porcine bile at $\mathrm{pH} 8.0$ for 45 minutes to simulate the intestinal environment. Following this treatment, we observed a reduction of about $1 \log$ in the bacterial count $(3.6$ $\left.\times 10^{7} \mathrm{CFU} \cdot \mathrm{mL}^{-1}\right)$. The reduction in bacterial counts during incubation in simulated intestinal juice was not statistically insignificant.

\subsection{Survival of L. fermentum TCUESCO1 under Commercial} Storage Conditions. To evaluate their survival during storage, L. fermentum bacteria were refrigerated at $4^{\circ} \mathrm{C}$ for 28 days in an otherwise sterile $10 \%$ nonfat milk acidified to $\mathrm{pH} 4.5$ with lactic acid (Figure 3). The bacterial strain was initially at a concentration of $3.6 \times 10^{9} \mathrm{CFU} \cdot \mathrm{mL}^{-1}$, but after 7 days of storage we observed a statistically significant reduction of approximately $1 \log$ in the bacterial count. From day 7 to day 21, there was unexpected growth from $4.3 \times 10^{8} \mathrm{CFU} \cdot \mathrm{mL}^{-1}$ to $9.0 \times 10^{8} \mathrm{CFU} \cdot \mathrm{mL}^{-1}$. By day 28 , the bacterial concentration had decreased to $2.83 \times 10^{8} \mathrm{CFU} \cdot \mathrm{mL}^{-1}$.

3.4. Autoaggregation of L. fermentum TCUESCO1. The bacteria increasingly aggregated until the fifth hour of in vitro culture, at which point a maximum of $70.19 \pm 1.78 \%$ aggregation was observed (Figure 4). However, the hourly increases

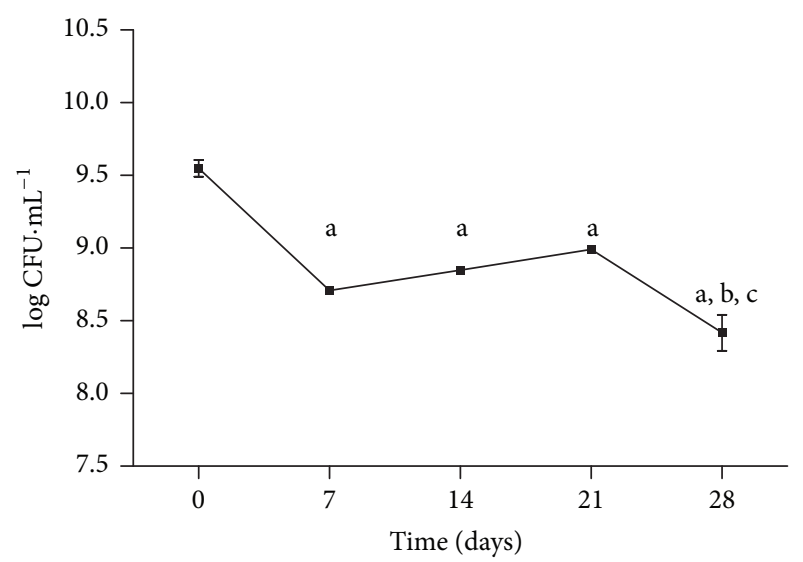

FIgURE 3: Survival of Lactobacillus fermentum TCUESC01 in fermented milk from 0 to 28 days, at $4^{\circ} \mathrm{C}$. Each point represents the average and standard deviation of three experiments. "a": statistically significant difference in relation to day zero $(p<0.05)$; "b": statistically significant difference in relation to day 14 ; " $c$ ": statistically significant difference in relation to day 21 .

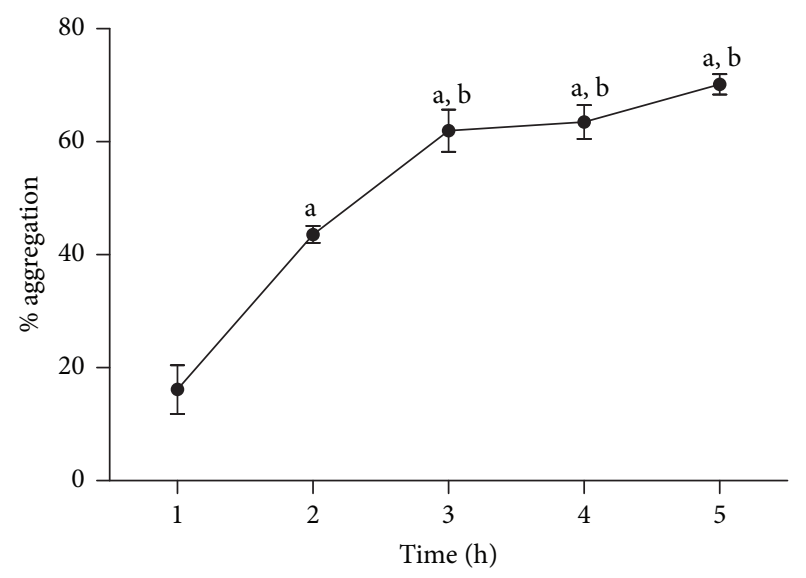

FIgURE 4: Percentage of autoaggregation of Lactobacillus fermentum TCUESC01 evaluated from the 1st to 5th hour of cultivation in MRS broth at $37^{\circ} \mathrm{C}$. "a": statistically significant difference in relation to the 1st hour of aggregation; "b": statistically significant difference in relation to the 2 nd hour of aggregation, $p<0.05$. Each point represents the average and standard deviation of 3 experiments.

in the percent aggregation were only statistically significant until the third hour of the experiment $(p<0.05)$.

3.5. Susceptibility of L. fermentum TCUESC01 to Antibiotics. This strain of L. fermentum showed susceptibility to the majority of antibiotics tested (Table 2). The few exceptions were the fluoroquinolones norfloxacin and ciprofloxacin, the nucleic acid synthesis inhibitors sulfonamide and cotrimoxazole (sulfamethoxazole and trimethoprim), the cell wall synthesis inhibiting glycopeptide antibiotic vancomycin, and the cell wall synthesis inhibiting $\beta$-lactam cefoxitin. L. fermentum TCUESCO1 was susceptible to amoxicillin, amoxicillin and clavulanic acid, penicillin $\mathrm{G}$, the $\beta$-lactams cefotaxime and cefalotin, the aminoglycosides amikacin and 
TABLE 2: Susceptibility of L. fermentum TCUESC01 to antibiotics.

\begin{tabular}{|c|c|c|}
\hline Antibiotic & $\begin{array}{c}\text { Zone of } \\
\text { inhibition } \\
(\mathrm{mm})^{*}\end{array}$ & Characterization $^{* *}$ \\
\hline Amikacin & 19 & $S$ \\
\hline Amoxicillin & 47 & $S$ \\
\hline $\begin{array}{l}\text { Amoxicillin and clavulanic } \\
\text { acid }\end{array}$ & 43 & $S$ \\
\hline Azithromycin & 30 & $S$ \\
\hline Cefalotin & 23 & $S$ \\
\hline Cefotaxime & 35 & $S$ \\
\hline Cefoxitin & 12 & $R$ \\
\hline Ciprofloxacin & 0 & $R$ \\
\hline Clindamycin & 14 & $S$ \\
\hline Chloramphenicol & 30 & $S$ \\
\hline Cotrimoxazole & 0 & $R$ \\
\hline Erythromycin & 33 & $S$ \\
\hline Streptomycin & 13 & MS \\
\hline Gentamicin & 15 & $S$ \\
\hline Imipenem & 57 & $S$ \\
\hline Norfloxacin & 0 & $R$ \\
\hline Penicillin G & 30 & $S$ \\
\hline Sulfonamides & 0 & $R$ \\
\hline Tetracycline & 20 & $S$ \\
\hline Vancomycin & 0 & $R$ \\
\hline
\end{tabular}

${ }^{*}$ Diameters are shown. ${ }^{* *}$ Based on standards shown in Table 1, L. fermentum TCUES01 is characterized as either susceptible $(S)$, moderately susceptible (MS), or resistant $(R)$ to each antibiotic tested.

gentamycin, the lincosamide clindamycin, the carbapenem imipenem, the macrolides azithromycin and erythromycin, the phenicol chloramphenicol, and tetracycline. The strain was also moderately susceptible to streptomycin.

\section{Discussion}

Guidelines established by the FAO and WHO affirm the need to analyze the functional properties and safety of bacteria before proposing its use in a food matrix [5]. We initially evaluated the capacity of this species of Lactobacillus to grow and survive at different $\mathrm{pH}$, and although it exhibited growth only in the range from $\mathrm{pH} 5$ to $\mathrm{pH} 7$, it remained viable during 10-h incubations at all $\mathrm{pH}$ levels evaluated, with the exception of $\mathrm{pH}$ 2. Studies have demonstrated wide variability in the gastric $\mathrm{pH}$ when the stomach is empty [9-11], with average values lower than $\mathrm{pH} 4$ [12]. The intestinal environment is more stable and varies between $\mathrm{pH} 6$ and $\mathrm{pH} 8$, depending on the intestinal region evaluated $[13,14]$. Therefore, even though this lactic bacterium has not shown the capacity to multiply or survive below $\mathrm{pH} 2.5$, it remains viable in the intestinal $\mathrm{pH}$ range and therefore may be able to function in that environment. Consistent with our data, Lactobacillus plantarum (ST194BZ, ST414BZ, and ST664BZ), Lactobacillus rhamnosus (ST461BZ, ST462BZ), and Lactobacillus paracasei
(ST242BZ, ST284BZ) isolated from a commonly consumed fermented drink (Boza) from the Balkan Peninsula showed good rates of growth during $10 \mathrm{~h}$ of incubation between $\mathrm{pH}$ 5 and $\mathrm{pH} 7$ [15]. L plantarum 423 isolated from sorghum drink, L. plantarum 241 isolated from pig ileum, L. curvatus DF38 isolated from salami, and Lactococcus lactis ssp. lactis HV219 isolated from human vaginal secretions also showed growth between $\mathrm{pH} 5$ and $\mathrm{pH} 6.5$ in similar experiments [16]. Overall, our results demonstrate that L. fermentum TCUESC01 has growth and $\mathrm{pH}$ resistance similar to other potential extraintestinal probiotic bacteria. Furthermore, the sensitivity of the strain to $\mathrm{pH}$ levels lower than 2.5 can be overcome by the use of methods that protect the bacteria, such as microencapsulation $[17,18]$. Our results support the potential application of this strain as a probiotic additive in foods with distinctly acidic characteristics, for example, cheeses, juices, and fermented milk.

The gastrointestinal environment can be hostile for many bacteria; a variety of stressors such as acidity, digestive enzymes, and biliary salts may negatively influence their survival during transit to the intestine [19]. The Lactobacillus in this study showed a discrete quantitative reduction but remained viable under gastric and intestinal conditions and resisted a concentration of bile three times that found in the human intestine $(0.3 \%)$ [20]. Similar to our data, Kaushik et al. [20] observed that Lactobacillus plantarum Lp9 decreased by about $0.5 \log$ from its initial concentration when exposed to conditions that mimic the stomach $(\mathrm{pH} 2)$ and $1 \log$ when exposed to conditions that mimic the intestine. In another study, L. rhamnosus VT1/1 isolated from cheese showed a reduction approximately $2 \log$ in concentration under low $\mathrm{pH}$ conditions ( $\mathrm{pH} 3$ ) and a reduction of $1 \log$ in concentration when incubated at $\mathrm{pH} 7$ in the presence of $2 \%$ biliary salts [21]. Our results suggest that $L$. fermentum could move through the gastrointestinal system and survive in concentrations above $10^{7} \mathrm{CFU} \cdot \mathrm{g}^{-1}$ (or CFU. $\mathrm{mL}^{-1}$ ), which previous studies suggest would be sufficient to interact and/or interfere with the host environment [22-24].

The food matrix is also an influencing factor in the viability of microorganisms during their storage [18, 25]. In testing the long-term survival of L. fermentum TCUESC01 in acidified milk, we observed an initial reduction of the bacterial counts followed by a slight increase from day 7 to day 21 . This growth can be explained by continued bacterial metabolism in the lactic solution, although at a reduced rate due to the low temperature. Donkor et al. [26] also observed quantitative variation in probiotic bacteria during storage at $4^{\circ} \mathrm{C}$, especially Lactobacillus delbrueckii ssp. bulgaricus Lb1466 that exhibited growth of $1 \log$ from day 7 to day 14 of cold storage. In another study, L. plantarum stored in fermented milk significantly reduced its cellular concentration by $1 \log$ during approximately 28 days of storage at $4^{\circ} \mathrm{C}$ [27]. Although L. fermentum had exhibited a decrease of $1 \log$ from its initial concentration by the last day of storage, its concentration was above average on the expiration date of the lactic solution [28]. Similarly, based on the recommendations of the National Agency for Sanitary Monitoring (ANVISA), L. fermentum TCUESC01 could be introduced into food 
matrices similar to fermented milk and survive in adequate concentrations until the expiration date of the product [29].

Microorganisms with the ability to autoaggregate remain in the intestines for a longer time and thus have better interactions with epithelial cells and the host immune system [30]. The L. fermentum TCUESC01 strain demonstrated an elevated capacity for autoaggregation in our 5-h trial. This result is higher than that reported by Beganović et al. [31], who demonstrated that L. fermentum A8 had $60.9 \pm 3.91 \%$ autoaggregation after $5 \mathrm{~h}$ of incubation, or that reported by Bao et al. [32], who demonstrated autoaggregation of less than $28 \%$ for 10 strains of $L$. fermentum after a 20 -h incubation. Based on our results, L. fermentum aggregates well and if ingested would likely be able to persist in the human intestinal environment for long time periods.

Finally, we evaluated susceptibility of TCUESC01 to a variety of antibiotics. Knowledge of antibiotic susceptibility is extremely important when we consider three important factors: the rare possibility of infection by Lactobacillus, the risk of horizontal transfer of resistance genes to native microbes, and the association between probiotic bacteria and antibiotic treatment. L. fermentum TCUESC01 exhibited susceptibility to the majority of the antibiotics, with the exception of nucleic acid synthesis inhibitors (norfloxacin, ciprofloxacin, sulfonamide, and cotrimoxazole) and two cell wall synthesis inhibitors (vancomycin and cefoxin). These results corroborate data published by Kirtzalidou et al. [33] on 74 strains of Lactobacillus ssp. isolated from human feces, of which $94.5 \%$ strains were resistant to amikacin, all were resistant to kanamycin and ciprofloxacin, $84.7 \%$ of strains were resistant to vancomycin, $1.6 \%$ strains were resistant to cefalotin, and $8.5 \%$ of strains were resistant to bacitracin. In general, lactobacilli show intrinsic resistance to quinolones, trimethoprim, sulfonamides, vancomycin, and the majority of nucleic acid inhibitors, while showing susceptibility to protein synthesis inhibitors with the exception of aminoglycosides [34-38]. It is worth noting that the resistance to antibiotics observed here is intrinsic to the genus as evident from published studies, and horizontal gene transfer is therefore uncommon. In summary, the resistance profile of L. fermentum TCUESC01 supports the possibility of use together with antibiotics that work by inhibiting nucleic acid synthesis.

\section{Conclusions}

Despite being an extraintestinal strain isolated during cocoa fermentation, L. fermentum TCUESC01 shows strong potential as a probiotic for application in food products. It remains viable across a wide $\mathrm{pH}$ spectrum and is therefore suitable for inclusion in different types of foods. When stored in a refrigerated milk product, it maintains viability above the levels recommended by recognized national and international organizations until the product expiration date. Under conditions that mimic gastrointestinal transit, it also survives in quantities sufficient for the maintenance of probiotic potential. In terms of its predicted behaviors within the intestines, L. fermentum TCUESC01 shows a strong tendency to autoaggregate. Finally, this strain exhibits antibiotic susceptibility and resistance profiles that will allow for its use alongside drug therapies. Taken together, these characteristics suggest L. fermentum TCUESC01 has great potential as a safe probiotic food additive.

\section{Conflicts of Interest}

The authors declare that they have no conflicts of interest.

\section{Acknowledgments}

This research was supported by a grant from the Fundação de Amparo a Pesquisa do Estado da Bahia (FAPESB). The Conselho de Desenvolvimento Científico e Tecnológico (CNPq) and the Coordenação de Aperfeiçoamento de Pessoal de nível Superior (CAPES) provided productivity and graduate fellowships for some authors.

\section{References}

[1] P. A. Bron, P. van Baarlen, and M. Kleerebezem, "Emerging molecular insights into the interaction between probiotics and the host intestinal mucosa," Nature Reviews Microbiology, vol. 10, no. 1, pp. 66-78, 2012.

[2] S. D. Todorov, M. B. Wachsman, H. Knoetze, M. Meincken, and L. M. T. Dicks, "An antibacterial and antiviral peptide produced by Enterococcus mundtii ST4V isolated from soya beans," International Journal of Antimicrobial Agents, vol. 25, no. 6, pp. 508-513, 2005.

[3] S. D. Todorov, J. W. von Mollendorff, E. Moelich, N. Muller, R. C. Witthuhn, and L. M. T. Dicks, "Evaluation of potential probiotic properties of Enterococcus mundtii, its survival in boza and in situ bacteriocin production," Food Technology and Biotechnology, vol. 47, no. 2, pp. 178-191, 2009.

[4] T. Ferreira Dos Santos, T. Alves Melo, M. E. Almeida, R. Passos Rezende, and C. C. Romano, "Immunomodulatory effects of Lactobacillus plantarum Lp62 on intestinal epithelial and mononuclear cells," BioMed Research International, vol. 2016, Article ID 8404156, 2016.

[5] Food and Agriculture Organization of the United Nations and the World Health Organization, Guidelines for the Evaluation of Probiotics in Food. Report of a Joint FAO/WHO Working Group meeting on drafting Guidelines for the Evaluation of Probiotics in Food, World Health Organization, London, Ontario, Canada, 2002.

[6] W. P. Charteris, P. M. Kelly, L. Morelli, and J. K. Collins, "Antibiotic susceptibility of potentially probiotic Lactobacillus species," Journal of Food Protection, vol. 61, no. 12, pp. 1636-1643, 1998.

[7] NCCLS, "Performance standards for antimicrobial disk susceptibility tests; approved standard," in S. NCCLS document M2-A8, NCCLS, 940 West Valley Road, Suite 1400, Wayne, Pennsylvania 19087-1898 USA, 8th edition.

[8] Clinical and Laboratory Standards Institute, Performance Standards for Antimicrobial Susceptibility Testing, Sixteenth Informational Supplement, Clinical and Laboratory Standards Institute, 940 West Valley Road, Suite 1400, Wayne, Pennsylvania, $\mathrm{Pa}$, USA, 2006. 
[9] S. Erkkilä and E. Petäjä, "Screening of commercial meat starter cultures at low $\mathrm{pH}$ and in the presence of bile salts for potential probiotic use," Meat Science, vol. 55, no. 3, pp. 297-300, 2000.

[10] R. P. Ross, C. Desmond, G. F. Fitzgerald, and C. Stanton, "Overcoming the technological hurdles in the development of probiotic foods," Journal of Applied Microbiology, vol. 98, no. 6, pp. 1410-1417, 2005.

[11] P. Ritter, C. Kohler, and U. V. Ah, "Evaluation of the passage of Lactobacillus gasseri $\mathrm{K} 7$ and bifidobacteria from the stomach to intestines using a single reactor model," BMC Microbiology, vol. 9, article no. 87, 2009.

[12] R. Tutuian, D. O. Castell, S. Xue, and P. O. Katz, "The acidity index: a simple approach to the measurement of gastric acidity," Alimentary Pharmacology and Therapeutics, vol. 19, no. 4, pp. 443-448, 2004.

[13] D. F. Evans, G. Pye, R. Bramley, A. G. Clark, T. J. Dyson, and J. D. Hardcastle, "Measurement of gastrointestinal $\mathrm{pH}$ profiles in normal ambulant human subjects," Gut, vol. 29, no. 8, pp. 10351041, 1988.

[14] G. Pye, D. F. Evans, S. Ledingham, and J. D. Hardcastle, "Gastrointestinal intraluminal $\mathrm{pH}$ in normal subjects and those with colorectal adenoma or carcinoma," Gut, vol. 31, no. 12, pp. 1355-1357, 1990.

[15] S. D. Todorov, M. Botes, C. Guigas et al., "Boza, a natural source of probiotic lactic acid bacteria," Journal of Applied Microbiology, vol. 104, no. 2, pp. 465-477, 2008.

[16] M. Brink, S. D. Todorov, J. H. Martin, M. Senekal, and L. M. T. Dicks, "The effect of prebiotics on production of antimicrobial compounds, resistance to growth at low $\mathrm{pH}$ and in the presence of bile, and adhesion of probiotic cells to intestinal mucus," Journal of Applied Microbiology, vol. 100, no. 4, pp. 813-820, 2006.

[17] S.-J. Kim, S. Y. Cho, S. H. Kim et al., "Effect of microencapsulation on viability and other characteristics in Lactobacillus acidophilus ATCC 43121," LWT - Food Science and Technology, vol. 41, no. 3, pp. 493-500, 2008.

[18] T. Heidebach, P. Först, and U. Kulozik, "Microencapsulation of probiotic cells by means of rennet-gelation of milk proteins," Food Hydrocolloids, vol. 23, no. 7, pp. 1670-1677, 2009.

[19] M. Kleerebezem, P. Hols, E. Bernard et al., "The extracellular biology of the lactobacilli," FEMS Microbiology Reviews, vol. 34, no. 2, pp. 199-230, 2010.

[20] J. K. Kaushik, A. Kumar, R. K. Duary, A. K. Mohanty, S. Grover, and V. K. Batish, "Functional and probiotic attributes of an indigenous isolate of Lactobacillus plantarum," PLoS ONE, vol. 4, no. 12, Article ID e8099, 2009.

[21] M. Succi, P. Tremonte, A. Reale et al., "Bile salt and acid tolerance of Lactobacillus rhamnosus strains isolated from Parmigiano Reggiano cheese," FEMS Microbiology Letters, vol. 244, no. 1, pp. 129-137, 2005.

[22] R. Ducluzeau, P. Raibaud, and R. Raibaud, Ecologie microbienne du tube digestif: ces microbes qui nous protègent, vol. 2, Masson, Paris, 1979.

[23] F. J. Penna, L. A. Filho, A. C. Calçado, H. R. Junior, and J. R. Nicolli, "Up-to-date clinical and experimental basis for the use of probiotics," Jornal de Pediatria, vol. 76, no. 7, pp. 209-17, 2000.

[24] S. M. I. Saad, "Probióticos e prebióticos: o estado da arte," Brazilian Journal of Pharmaceutical Science, vol. 42, pp. 1-16, 2006.

[25] C. Stanton, G. Gardiner, P. B. Lynch, J. K. Collins, G. Fitzgerald, and R. P. Ross, "Probiotic cheese," International Dairy Journal, vol. 8, no. 5-6, pp. 491-496, 1998.
[26] O. N. Donkor, A. Henriksson, T. Vasiljevic, and N. P. Shah, "Effect of acidification on the activity of probiotics in yoghurt during cold storage," International Dairy Journal, vol. 16, no. 10, pp. 1181-1189, 2006.

[27] R. Georgieva, I. Iliev, T. Haertlé, J. Chobert, I. Ivanova, and S. Danova, "Technological properties of candidate probiotic Lactobacillus plantarum strains," International Dairy Journal, vol. 19, no. 11, pp. 696-702, 2009.

[28] A. C. Ouwehand and S. J. Salminen, "The health effects of cultured milk products with viable and non-viable bacteria," International Dairy Journal, vol. 8, no. 9, pp. 749-758, 1998.

[29] ANVISA, "Alimentos com alegações de propriedades funcionais e ou de saúde, novos alimentos/ingredientes, substâncias bioativas e probióticos," http://www.anvisa.gov.br/ alimentos/comissoes/tecno_lista_alega.htm, 2016.

[30] T. S. Kemgang, S. Kapila, V. P. Shanmugam, and R. Kapila, "Cross-talk between probiotic lactobacilli and host immune system," Journal of Applied Microbiology, vol. 117, no. 2, pp. 303319, 2014.

[31] J. Beganović, J. Frece, B. Kos, A. Leboš Pavunc, K. Habjanič, and J. Šušković, "Functionality of the S-layer protein from the probiotic strain Lactobacillus helveticus M92," Antonie van Leeuwenhoek, International Journal of General and Molecular Microbiology, vol. 100, no. 1, pp. 43-53, 2011.

[32] Y. Bao, Y. Zhang, Y. Zhang et al., "Screening of potential probiotic properties of Lactobacillus fermentum isolated from traditional dairy products," Food Control, vol. 21, no. 5, pp. 695701, 2010.

[33] E. Kirtzalidou, P. Pramateftaki, M. Kotsou, and A. Kyriacou, "Screening for lactobacilli with probiotic properties in the infant gut microbiota," Anaerobe, vol. 17, no. 6, pp. 440-443, 2011.

[34] W. P. Charteris, P. M. Kelly, L. Morelli, and J. K. Collins, "Development and application of an in vitro methodology to determine the transit tolerance of potentially probiotic Lactobacillus and Bifidobacterium species in the upper human gastrointestinal tract," Journal of Applied Microbiology, vol. 84, no. 5, pp. 759-768, 1998.

[35] R. Coppola, M. Succi, P. Tremonte, A. Reale, G. Salzano, and E. Sorrentino, "Antibiotic susceptibility of Lactobacillus rhamnosus strains isolated from Parmigiano Reggiano cheese," Lait, vol. 85, no. 3, pp. 193-204, 2005.

[36] S. Mathur and R. Singh, "Antibiotic resistance in food lactic acid bacteria-a review," International Journal of Food Microbiology, vol. 105, no. 3, pp. 281-295, 2005.

[37] I. Klare, C. Konstabel, G. Werner et al., "Antimicrobial susceptibilities of Lactobacillus, Pediococcus and Lactococcus human isolates and cultures intended for probiotic or nutritional use," Journal of Antimicrobial Chemotherapy, vol. 59, no. 5, pp. 900912, 2007.

[38] M. Nawaz, J. Wang, A. Zhou et al., "Characterization and transfer of antibiotic resistance in lactic acid bacteria from fermented food products," Current Microbiology, vol. 62, no. 3, pp. 1081-1089, 2011. 

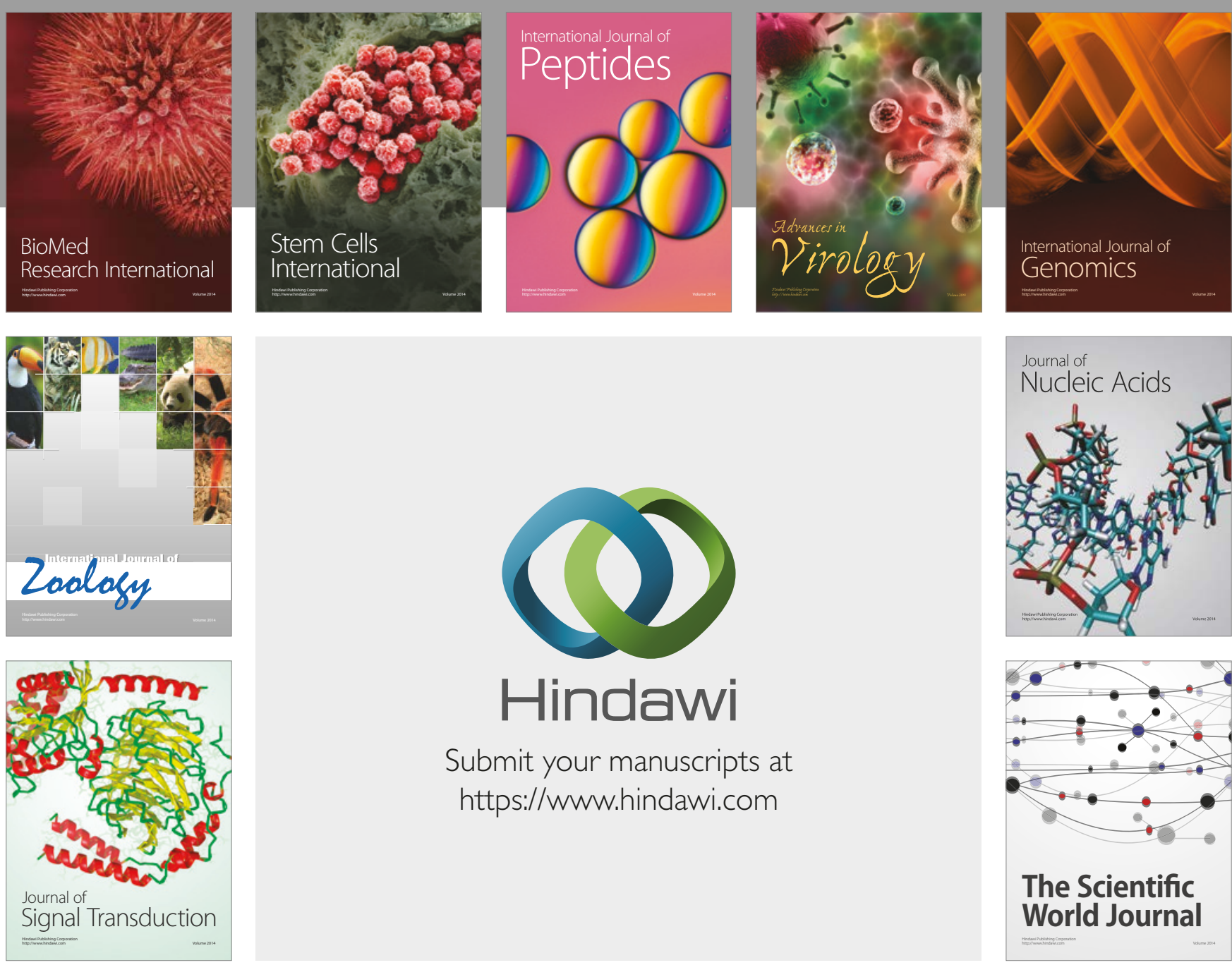

Submit your manuscripts at

https://www.hindawi.com
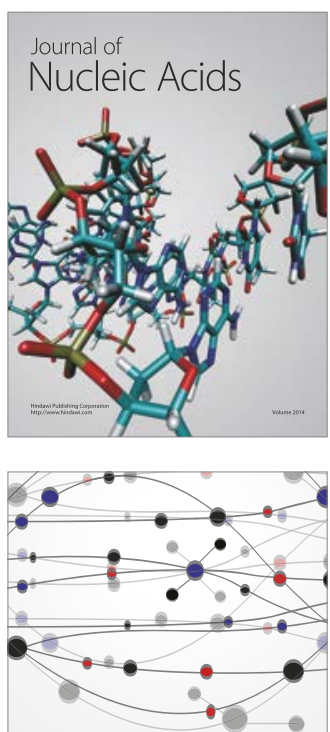

The Scientific World Journal

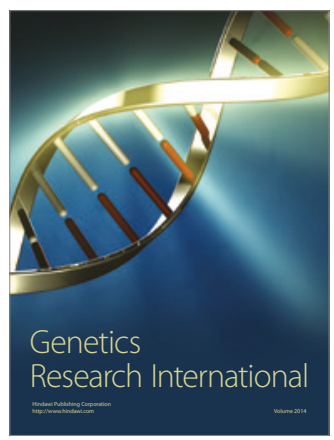

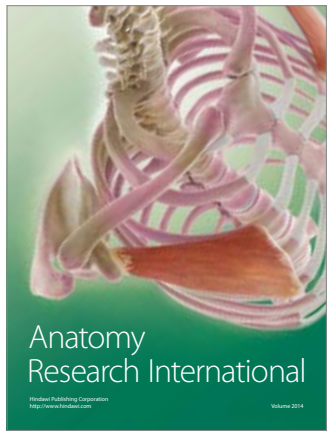

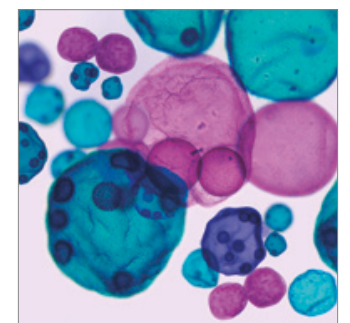

International Journal of Microbiology
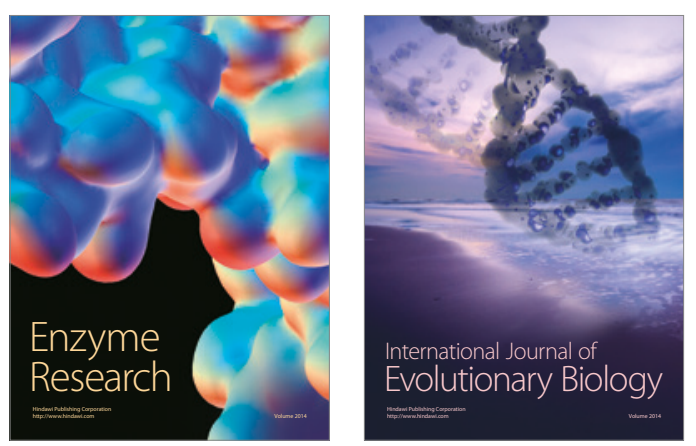
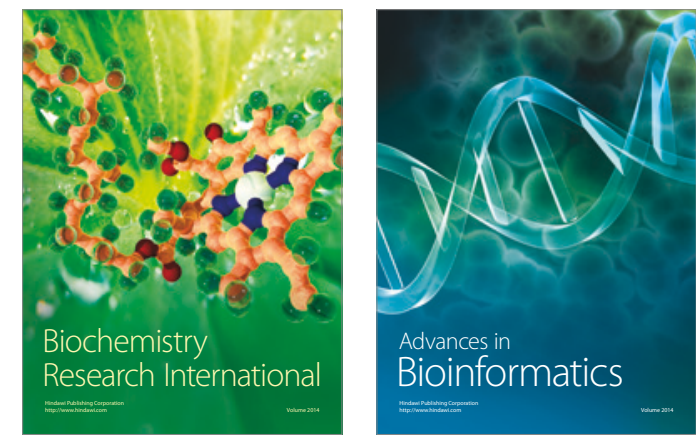

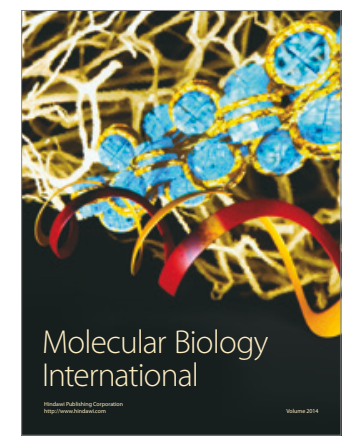

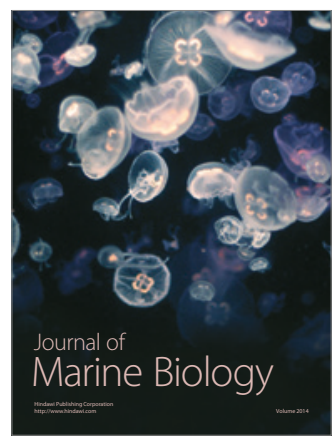

